\title{
SINDROM SAGORIJEVANJA MEDICINSKIH SESTARA U DOMU ZDRAVLJA MOSTAR ZA VRIJEME COVID-19 PANDEMIJE
}

\author{
Katarina Tomić ${ }^{1}$, Darjan Franjić ${ }^{2}$, Krešimir Tomić ${ }^{2}$, Edita Černy Obrdalj ${ }^{1}$ \\ ${ }^{1}$ Fakultet zdravstvenih studija Sveučilišta u Mostaru \\ ${ }^{2}$ Klinika za onkologiju, Sveučilišna klinička bolnica Mostar
}

Rad je primljen 03.07.2021. Rad je recenziran 27.07.2021. Rad je prihvaćen 29.08.2021.

\section{SAŽ̃TAK}

UVOD: Poziv medicinske sestre svrstan je u visoko stresne profesije i s velikim rizikom za razvoj sindrom sagorijevanja s obzirom na visoku odgovornost prema ljudskom životu i zdravlju, ali i izloženosti različitim stresogenim faktorima na radnom mjestu. Sindrom sagorijevanja kod medicinskih sestara u Domu zdravlja Mostar za vrijeme pandemije koronavirusne bolesti 2019 (engl. Coronavirus disease 2019, COVID-19) nije istražen.

CILJ: Utvrditi učestalost $\mathrm{i}$ intenzitet sindroma sagorijevanja i prisutnost psihosocijalnih rizika na radnom mjestu $\mathrm{u}$ medicinskih sestara za vrijeme COVID-19 pandemije.

METODE: Istraživanje je provedeno u svibnju 2020. godine kod 37 medicinskih sestara koji su zaposleni u Domu zdravlja Mostar. Za prikupljanje podataka korišten je sociodemografski upitnik namjenski sačinjen za ovo istraživanje i samokreirani upitnik za procjenu razine sagorijevanja.

REZULTATI: Statistički značajno najveći broj medicinskih sestara smatra da može ispuniti zahtjeve svojih nadređenih, da se rijetko ne slažu s načinom obavljanja poslova, da ih nadređeni nikad previše ne kontrolira prilikom obavljanja poslova te da nikad ne moraju obavljati nekoliko poslova istovremeno. Statistički značajno najveći broj medicinskih sestara nije doživjelo neugodne prijetnje kolega i obavljanje teških fizičkih poslova na neprimjeren način. Statistički značajno najveći broj medicinskih sestra se boje za dobivanje otkaza te smatraju da je ritam rada prebrz za vrijeme pandemije COVID-19.

ZAKLJUČAK: Za vrijeme COVID-19 pandemije zabilježena je prisutnost sindroma sagorijevanja kod medicinskih sestara.

Ključne riječi: Stres, sindrom sagorijevanja, posao, medicinska sestra

Autor za korespondenciju:

Darjan Franjić, MA, doktorand

E-mail: darjanfranjic@gmail.com 


\section{UVOD}

Istraživanja mentalnog zdravlja kod zdravstvenih djelatnika važna su jer psihološke teškoće zdravstvenih djelatnika, osim što utječu na njihovo osobno i profesionalno funkcioniranje, mogu znatno utjecati i na kvalitetu skrbi o pacijentima (1). Sindrom profesionalnog sagorijevanja podrazumijeva osjećaj iscrpljenosti, gubitak energije, gubitak idealizma i motivacije, bespomoćnost, frustraciju, udaljavanje od posla, sumnju u vlastite profesionalne sposobnosti i shvaćanje klijenta kao da je predmet. Osobe često ne shvaćaju da se s njima nešto dešava i da su u procesu sindroma profesionalnog sagorijevanja. Često se sa sindromom sagorijevanja povezuju i različite psihičke i fizičke promjene: nesanica, bolesti ovisnosti, glavobolje, promjene ponašanja, depresija, anksioznost, bolesti srca i krvnih žila, bolesti probavnog sustava. Osobe koje su pod utjecajem sindroma profesionalnog sagorijevanja češće rade greške u svom poslu, koriste bolovanje, daju otkaz i ulaze u sukobe s kolegama (2).

Poziv medicinske sestre svrstan je u visoko stresne profesije $s$ obzirom na visoku odgovornost prema ljudskom životu i zdravlju, ali i izloženosti specifičnim stresorima poput kemijskih, bioloških i fizikalnih štetnosti te smjenskom radu, kao i svakodnevnim suočavanjem sa smrti pacijenata. Produljeno radno vrijeme, smjenski i noćni rad, odgovornost pri donošenju odluka, kontakt $s$ oboljelima i njihovim obiteljima te emocionalno iscrpljivanje pridonose povećanom morbiditetu od psihičkih smetnji i psihosomatskih bolesti (3).

Prvi pacijent sa dijagnozom koronavirusne bolesti 2019 (engl. Coronavirus Disease 2019 - COVID-19) je verificiran u ožujku 2020. godine na području Federacije Bosne i Hercegovine (4). U literaturi je objavljen veći rizik za pojavu sindroma sagorijevanja kod zdravstvenih djelatnika tijekom COVID-19 pandemije (5). Sindrom sagorijevanja (engl. burnout) je sindrom emocionalne iscrpljenosti, depersonalizacije i smanjenja osobnog postignuća koji nastaje kao odgovor na kroničan stres u poslovima vezanim uz neposredan rad s ljudima (6). Simptomi sagorijevanja na radnom mjestu su opadanje učinkovitosti, smanjenje inicijative, opadanje interesa za posao te progresivno smanjivanje sposobnosti održavanja učinka u razdobljima stresa $(7,8)$.

Cilj ovog istraživanja bio je utvrditi učestalost i intenzitet sindroma sagorijevanja i prisutnost psihosocijalnih rizika na radnom mjestu kod medicinskih sestara u Domu zdravlja Mostar za vrijeme COVID-19 pandemije

\section{MATERIJALI I METODE}

Istraživanje je provedeno kao presječna studija u Domu zdravlja Mostar u svibnju 2020. godine. U istraživanju je sudjelovalo 37 medicinskih sestara, a podaci su dobiveni ispunjavanjem anketnog upitnika. Anketa je bila anonimna, a sudjelovanje dobrovoljno. Svim ispitanicima, čijim se kontaktom raspolagalo, poslan je online upitnik na e-adresu koju su naveli. Za prikupljanje podataka korišten je sociodemografski upitnik namjenski sačinjen za ovo istraživanje i samokreirani upitnik za procjenu razine sagorijevanja od strane voditelja istraživanja. Pitanja u anketi su se odnosila na sociodemografske podatke (dob, stupanj obrazovanja, radni staž) i zadovoljstvo o poslom (25 pitanja, Likertova skala od 1 do 5). Za procjenu prisutnosti određenih ponašanja kod analiziranih medicinskih sestara ispitanicima je ponuđeno 18 tvrdnji u kojima su trebali zaokružiti jedan od tri ponuđena odgovora (nikad, često, uvijek).

U studiju su uključene medicinske sestre Doma zdravlja Mostar starije od 18 godina koje su bile dostupne i koje su dobrovoljno obznanile svoju e-mail adresu. U istraživanje su uključene samo one medicinske sestre koje su pristale dobrovoljno sudjelovati u istraživanju. Uključene su medicinske sestre koje poznaju hrvatski jezik (čitanje i pisanje) i koje su u mogućnosti samostalno ispuniti upitnik. Iz istraživanja su isključene one medicinske sestre koje su nevaljano ispunile upitnik. Valjano ispunjeni smatrali su se oni upitnici u kojima su pacijenti odgovorili na sva pitanja i tvrdnje.

Prije provođenja istraživanja traženo je dopuštenje etičkog povjerenstva Doma zdravlja, Mostar. Ispitanici su upoznati sa svim mogućim prednostima, nedostatcima, rizicima i posljedicama sudjelovanja $\mathrm{u}$ istraživanju, a morali su dati svoj pismeni pristanak na sudjelovanje $\mathrm{u}$ istraživanju te su imali pravo u svakom trenutku odustati od istraživanja bez dodatnih objašnjenja. Povjerljivost je dobivena šifriranjem osobnih podataka, a popis imena i pripadajuće šifre voditelj istraživanja čuvao je na povjerljivom i sigurnom mjestu.

Statistička obrada podataka

Prikupljeni podatci obrađeni su metodom deskriptivne statistike. Za analizu podataka korišten je statistički software SPSS (engl. Statistical Package for Social Sciences) za Windows, verzija 26.0 (IBM, Armonk, New York, USA). Ovaj program je korisnički orijentiran program. Za analizu Gaussove normalnosti raspodjele podataka je korišten Kolmogorov-Smirnovljevim test (K-S test). Za procjenu statističke razlike među skupinama korišten je hi-kvadrat $(\chi 2)$ test jednakih frekvencija. Razina vjerojatnosti od $\mathrm{p}<0,05$ je uzeta kao statistički značajna. Raspršenje podataka definirano je $95 \%$ rasponom pouzdanosti, $95 \%$ 
CI (engl. Confidence Interval). Za prikaz mjera učinka korišten je OR (engl. Odds ratio).

\section{REZULTATI}

Najviše medicinskih sestara je u dobi od 31 do 40 godina, sa srednjom stručnom spremom i radnim stažom od 11 do 20 godina (Tablica 1 ).

Tablica 1. Razlike u broju ispitanika u odnosu na dob, obrazovanje i radni staž.

\begin{tabular}{lcccc}
\hline Karakteristike & $N$ & $\%$ & $\chi^{2}$ & $p$ \\
\hline Dob & 9 & $24 \%$ & & \\
$19-30$ & 13 & $34 \%$ & & \\
$31-40$ & 7 & $18 \%$ & & \\
$41-50$ & 7 & $21 \%$ & & \\
$51-60$ & 1 & $3 \%$ & & \\
$60<$ & & & 9,135 & 0,010 \\
Obrazovanje & 21 & $56 \%$ & & \\
SSS & 8 & $22 \%$ & & \\
vŠs & 8 & $22 \%$ & & \\
vSS & & & 5,486 & 0,139 \\
Radni staž & 12 & $33 \%$ & & \\
$0-10$ & 13 & $36 \%$ & & \\
$11-20$ & 8 & $20 \%$ & & \\
$21-30$ & 4 & $11 \%$ & & \\
$31<$ & 37 & $100 \%$ & \\
Ukupno & & & \\
\hline
\end{tabular}

$\mathrm{N}$ - broj ispitanika; $\chi^{2}$ - Hi-kvadrat test; SSS - Srednja stručna sprema;

VŠS - Viša stručna sprema; VSS - Visoka stručna sprema

U odnosu na pitanja o neodlučnosti na poslu, statistički značajno najveći broj medicinskih sestara nema problema kada odbijaju raditi prekovremeno $\left(\chi^{2}=41,243 ; \quad \mathrm{df}=4 ; \quad \mathrm{p}<0,001\right)$. Statistički značajno najveći broj medicinskih sestara može ispuniti proturječne zahtjeve svojih nadređenih $\left(\chi^{2}=15,027 ; \mathrm{df}=4 ; \mathrm{p}<0,05\right)$, te rijetko ima neslaganje s uputama poslodavca o načinu obavljanja poslova $\left(\chi^{2}=25,027 ; \mathrm{df}=4\right.$; $\mathrm{p}<0,001)$. Dvadeset medicinskih sestara misli kako kolege nemaju negativan odnos prema njima $\left(\chi^{2}=33,676\right.$; $\mathrm{df}=4 ; \mathrm{p}<0,001)$, dok njih 18 rijetko nije sigurno što kolege od njih očekuju $\left(\chi^{2}=28,270 ; \mathrm{df}=4 ; \mathrm{p}<0,001\right)$.

Statistički značajno najveći broj medicinskih sestara smatra kako rijetko ima previše "papirologije“ na svom poslu, kako posao povremeno utječe na njihov privatni život, kako ih nadređeni nikad previše ne kontrolira prilikom obavljanja poslova te da nikad ne moraju obavljati nekoliko poslova istovremeno (Tablica 2). 
Tablica 2. Stavovi medicinskih sestara u odnosu na pritisak na poslu.

\begin{tabular}{|c|c|c|c|c|c|c|c|}
\hline Tvrdnja & Nikad & Rijetko & Povremeno & Često & Uvijek & $x^{2}$ & $p$ \\
\hline $\begin{array}{l}\text { Imam previše papirologije na svom } \\
\text { poslu. }\end{array}$ & 3 & 19 & 7 & 7 & 1 & 26,378 & $<0,001$ \\
\hline $\begin{array}{l}\text { Obavljam poslove koji se moraju } \\
\text { obaviti na brzinu. }\end{array}$ & 2 & 7 & 14 & 8 & 5 & 9,351 & 0,053 \\
\hline $\begin{array}{l}\text { Moj posao previše utječe na moj } \\
\text { privatni život. }\end{array}$ & 6 & 11 & 13 & 5 & 2 & 10,973 & 0,027 \\
\hline $\begin{array}{l}\text { Nadređeni me previše kontroliraju } \\
\text { pri obavljanju poslova }\end{array}$ & 16 & 9 & 7 & 4 & 1 & 17,459 & 0,002 \\
\hline $\begin{array}{l}\text { Istovremeno moram obavljati } \\
\text { nekoliko poslova }\end{array}$ & 3 & 4 & 16 & 10 & 4 & 16,649 & 0,002 \\
\hline
\end{tabular}

Statistički značajno najveći broj medicinskih sestara se ne slaže s tvrdnjom da je nepoželjno ići na bolovanje $\left(\chi^{2}=31,243 ; \mathrm{df}=4 ; \mathrm{p}<0,001\right)$, nije doživjelo neugodne prijetnje kolega $\left(\chi^{2}=46,649\right.$; $\mathrm{df}=4 ; \quad \mathrm{p}<0,001)$ i obavljanje teških fizičkih poslova na neprimjeren način $\left(\chi^{2}=26,649 ; \mathrm{df}=4\right.$; $\mathrm{p}<0,001)$.
Statistički značajno najveći broj medicinskih sestra povremeno se boje da će dobiti otkaz (Tablica 3).

Tablica 3. Stavovi ispitanika u odnosu na sigurnost posla.

\begin{tabular}{|c|c|c|c|c|c|c|c|}
\hline Tvrdnja & Nikad & Rijetko & Povremeno & Često & Uvijek & $\chi^{2}$ & $p$ \\
\hline $\begin{array}{l}\text { Bojim se otkaza bez opravdanog } \\
\text { razloga. }\end{array}$ & 23 & 10 & 2 & 0 & 2 & 31,432 & $<0,001$ \\
\hline Za napredovanje je potrebna veza. & 8 & 6 & 16 & 2 & 5 & 15,027 & 0,005 \\
\hline $\begin{array}{l}\text { Zabrinuta sam za egzistenciju zbog } \\
\text { male plaće. }\end{array}$ & 2 & 7 & 19 & 3 & 6 & 25,027 & $<0,001$ \\
\hline Brinem zbog niske mirovine. & 4 & 7 & 15 & 2 & 1 & 13,676 & 0,008 \\
\hline Boïm se da ću dobiti otkaz. & 23 & 10 & 2 & 0 & 2 & 31,865 & $<0,001$ \\
\hline
\end{tabular}

$\chi^{2}$ - Hi-kvadrat test

Statistički značajno najveći broj medicinskih sestara povremeno smatra kako je ritam rada prebrz za vrijeme pandemije COVID-19 $\left(\chi^{2}=17,452 ; \mathrm{df}=4 ; \mathrm{p}<0,05\right)$.

U odnosu na prisutnost određenog ponašanja, statistički značajno najveći broj medicinskih sestara smatra da im je posao veoma zamoran i rutinski (Tablica 4 ). 
Tablica 4. Prisutnost određenog ponašanja.

\begin{tabular}{|c|c|c|c|c|c|}
\hline Tvrdnje & Nikad & Često & Uvijek & $\chi^{2}$ & $\mathrm{p}$ \\
\hline 0sjećam neprijateljstvo i srdžbu na poslu. & 17 & 18 & 2 & 13,027 & 0,001 \\
\hline Primjećujem da se povlačim od kolega. & 22 & 13 & 2 & 16,270 & $<0,001$ \\
\hline Sve što se traži od mene da uradim, doživljavam kao prisilu. & 28 & 7 & 2 & 30,865 & $<0,001$ \\
\hline $\begin{array}{l}\text { Postajem sve neosjetljivija i bešćutnija prema klijentima i } \\
\text { kolegama. }\end{array}$ & 23 & 11 & 3 & 16,432 & $<0,001$ \\
\hline Posao je veoma zamoran i rutinski. & 13 & 18 & 6 & 5,892 & 0,053 \\
\hline $\begin{array}{l}\text { Primjećujem da mislim negativno o poslu i usmjeravam se } \\
\text { samo na njegove loše strane. }\end{array}$ & 22 & 11 & 4 & 13,351 & $<0,001$ \\
\hline 0sjećam da postižem mnogo manje nego prije. & 22 & 12 & 3 & 14,649 & $<0,001$ \\
\hline Imam teškoća u organiziranju svog posla i vremena. & 22 & 12 & 3 & 14,649 & $<0,001$ \\
\hline Razdražljivija sam nego prije. & 18 & 16 & 3 & 10,757 & 0,005 \\
\hline 0sjećam se nemoćnom da promijenim nešto na poslu. & 8 & 22 & 7 & 11,405 & 0,003 \\
\hline Frustracije izazvane poslom unosim i u privatni život. & 16 & 16 & 5 & 6,541 & 0,038 \\
\hline Više nego ikad svjesno izbjegavam osobne kontakte. & 18 & 17 & 2 & 13,027 & 0,001 \\
\hline Pitam se da li je moj posao prikladan za mene. & 24 & 7 & 6 & 16,595 & $<0,001$ \\
\hline 0 svom poslu mislim negativno, čak i navečer prije spavanja. & 25 & 9 & 3 & 20,973 & $<0,001$ \\
\hline $\begin{array}{l}\text { Svakom radnom danu pristupam sa mišlju: "Ne znam hoću li } \\
\text { izdržati još jedan dan". }\end{array}$ & 24 & 7 & 6 & 16,595 & $<0,001$ \\
\hline $\begin{array}{l}\text { Čini mi se da nikoga na poslu nije briga o onome na čemu } \\
\text { radim. }\end{array}$ & 24 & 8 & 5 & 16,595 & $<0,001$ \\
\hline Provodim više vremena izbjegavajući posao nego radeći. & 30 & 3 & 4 & 16,919 & $<0,001$ \\
\hline $\begin{array}{l}\text { Na poslu se osjećam umorno i iscrpljeno, čak i kad se dobro } \\
\text { naspavam. }\end{array}$ & 20 & 13 & 4 & 10,432 & 0,005 \\
\hline
\end{tabular}

$\chi^{2}-$ Hi-kvadrat test 


\section{RASPRAVA}

Rezultati ove studije pokazuju da najveći broj medicinskih sestara smatra da njihov posao povremeno utječe na njihov privatni život, da je poželjno ići na bolovanje, da ne obavljaju fizički teške poslove, da imaju brigu za zdravlje i sigurnost na radu. Iz prikazanih rezultata vidljivo je da najveći broj medicinskih sestara smatra kako se nikad ne boji otkaza bez opravdanog razloga te da je kod poslodavca potrebna „veza“ za napredovanje. Najveći broj medicinskih sestara je iskazalo zabrinutost za egzistenciju zbog male plaće ili mirovine. Nadalje, većina medicinskih sestara je zadovoljna vremenskim rokovima u kojima moraju obaviti zadatke na poslu. Važno je istaknuti da je statistički značajno veći broj medicinskih sestara iskazalo da često osjećaju neprijateljstvo i srdžbu na poslu, da im je posao zamoran i rutinski, da unose frustracije u privatni život te da se često osjećaju nemoćno da promijene nešto na poslu. Navedeni čimbenici pokazuju da ispitivane medicinske sestre imaju simptome koje ukazuju na sindrom sagorijevanja. Od početka pandemije COVID-19 provedena su brojna istraživanja koja su se bavila temom sindroma sagorijevanja kod medicinskih sestara i zdravstvenih djelatnika općenito. $U$ skladu s našim nalazima, istraživanja pokazuju kako su medicinski djelatnici izloženi puno većoj razini stresa na radnom mjestu u odnosu na opću populaciju u normalnim okolnostima, te su izloženi većem riziku od psihosomatskih bolesti (9-11). Za sindrom sagorijevanja poznato je da je u velikoj mjeri prisutan među zdravstvenim radnicima, a mogućnost za njegovu pojavu povećao je dodatni stres u poslu izazvanim pandemijom bolesti COVID-19. Brojke koje govore o velikom postotku zdravstvenih radnika zahvaćenih sindromom sagorijevanja pozivaju na žurnost $\mathrm{u}$ primjeni mjera prevencija, kao i kvalitetnih terapijskih pristupa za liječenje sindroma sagorijevanja u medicinskih sestara i liječnika. Postoji niz čimbenika koji djeluju protektivno u smislu razvoja i podržavanja rezilijencije, kao i niz čimbenika koji djeluju disruptivno na psihičko i tjelesno funkcioniranje. Otpornost i zdravi mehanizmi suočavanja sa stresom imaju protektivnu ulogu, ublažavaju posljedica stresa, kao i razinu traumatizacije stresnim događajima (12). Zbog toga je najpogodniji način za prevenciju sindroma sagorijevanja stavljanje fokusa na razvijanje pozitivnih psiholoških karakteristika osobe za nošenje sa stresom te modifikacija poslovnog okruženja u smjeru boljih uvjeta rada, a ne zasebni rad na jednom čimbeniku $(13,14)$. Zdravstveni radnici, medicinske sestre i liječnici pripadaju zanimanjima koja imaju najveće postotke sindroma sagorijevanja, što je dodatno povećano krizom koju je izazvala pandemija bolesti COVID-19 (15).

Tijekom pandemije, zdravstveni djelatnici su se morali izolirati od vlastite obitelji iz straha da će virus prenijeti svojim najmilijima. Krivnju će osjećati ukoliko se član obitelji zarazi. Zdravstveni djelatnici hrabro žive u stalnom stanju psihološkog stresa utemeljenog na strahu; strah od prenošenja virusa i strah od nepoznatog vezanog uz bolest COVID-19. Kineski istraživači proveli su presječnu studiju u ožujku 2020. U istraživanju je sudjelovalo 1257 zdravstvenih djelatnika u Kini tijekom pandemije COVID19. Izvijestili su zabrinjavajuće rezultate koji ukazuju da je rad na prvoj liniji bio neovisni faktor rizika za lošije rezultate mentalnog zdravlja zdravstvenih djelatnika. Psihički simptomi značajno pridonosi izgaranju među zdravstvenim radnicima, a ponajprije medicinskim sestrama koje u najvećoj mjeri skrbe o pacijentima oboljelih od COVID-19 bolesti. Stoga ih se ne smije zanemarivati. Nasuprot, potrebno je istraživati njihovu prisutnost kod zdravstvenih djelatnika za vrijeme pandemije COVID-19 (16). Naši rezultati potvrđuju rezultate Cochrane sustavnog preglednog rada kojeg su proveli Galanis i suradnici 2021. godine (17). Rezultati njihovog rada pokazuju da sindrom sagorijevanja medicinskih sestara predstavlja krucijalni problem tijekom COVID-19 pandemije. Oni navode da je iznimno važno adekvatno pripremiti medicinske sestre za bolje suočavanje i nošenje s izazovima koje predstavlja COVID-19 bolest. Mnogi autori navode da se prevalenca sindroma sagorijevanja razlikuje ovisno o zemljopisnim obilježjima i specijalnostima. Na primjer, Središnja Azija i Europa imaju najnižu, a područje Južne Afrike najvišu prevalencu sindroma sagorijevanja medicinskih sestara $(18,19)$. U skladu s rezultatima ove studije, mnoge dosadašnje studije pokazuju da loše zadovoljstvo uvjetima radnog mjesta utječe na pojavu sindroma sagorijevanja kod medicinskih sestara za vrijeme pandemije COVID-19 (20, 21). Dosadašnja istraživanja navode da je pojavnost sindroma sagorijevanja u vrijeme pandemije COVID-19 viša u medicinskih sestara koji rade na stresnijim odjelima kao što je onkologija, pedijatrija i intenzivna njega, a niža razina sindroma sagorijevanja je zabilježena u medicinskih sestara koji rade na odjelima primarne zdravstvene njege $(22,23)$. Čak štoviše, mnoge studije da navode da je upravo u onkoloških medicinskih sestara zabilježena najviša razina sindroma sagorijevanja (24-26). Dosadašnje studije navode da provođenje psiholoških intervencija utječe na manju razinu stresa i sindroma sagorijevanja kod medicinskih sestara za vrijeme pandemije COVID-19, što doprinosi višoj razini radne učinkovitosti i samopouzdanja prilikom obavljanja poslova (27-29). 
Tomić K, Franjić D, Tomić K, Černy Obrdalj E. Sindrom sagorijevanja medicinskih sestara u Domu zdravlja Mostar za vrijeme covid-19 pandemije. Zdravstveni glasnik. 2021;7(2):59-66.

\section{ZAKLJUČAK}

Medicinske sestre često osjećaju neprijateljstvo, zamor i osjećaj rutine na poslu. Za vrijeme COVID-19 pandemije zabilježena je prisutnost sindroma sagorijevanja kod medicinskih sestara. Da bi se spriječila učestala pojavnost sindroma sagorijevanja kod medicinskih sestara potrebno je adekvatno pripremiti medicinske sestre za rad s pacijentima u vrijeme pandemije COVID-19.

\section{LITERATURA}

1. Sviben R, Pukljak-Iričanin Z, Lauri-Korajlija A, Čular-Reljanović I. Sindrom sagorijevanja i mentalno zdravlje kod medicinskog osoblja sa psihijatrijskog i nepsihijatrijskih odjela. JAHS. 2017;3(2):169-181.

https://doi.org/10.24141/1/3/2/4

2. Tomljenović M. Sindrom profesionalnog sagorijevanja - „Burnout syndrom“. Nar Zdr List [Internet]. 2013;644-645(55):32.

3. Kos-Bojanović H. Izgaranje medicinskih sestara na odjelima kirurških djelatnosti u OB "Dr. Tomislav Bardek” Koprivnica. Varaždin; 2016.

4. Arapović J, Skočibušić S. The first two months of the COVID-19 pandemic in Bosnia and Herzegovina: Single-center experience. Bosn J Basic Med Sci. 2020 Aug 3;20(3):396-400.

5. Sunjaya DK, Herawati DMD, Siregar AYM. Depressive, anxiety, and burnout symptoms on health care personnel at a month after COVID-19 outbreak in Indonesia. BMC Public Health. 2021 Jan 28;21(1):227.

6. Maslach C. Burnout, the cost of caring. NJ: Upper Saddle River: Prentice Hall; 1982.

7. Freudenberger HJ. Staff burn-out. J Soc Issues. 1974;30(1):159-165.

8. Bahtijarević-Šiber F. Management ljudskih potencijala. Zagreb: Golden Marketing; 1999.

9. Huang L, Zhang Y, Yao YC, Cui FF, Shi T, Wang YW, et al. Effects of personality and psychological acceptance on medical workers' occupational stress. Chinese Journal of Industrial Hygiene and Occupational Diseases. 2018;36(7):519-522.

10. Polyakova OB, Boncalo TI. Features of psychosomatization of medical personnel with occupational deformities. Probl Sotsialnoi Gig Zdravookhranenniiai Istor Med. 2020 Oct;28(Special Issue):1195-1201.

11. Waddill-Goad SM. Stress, fatigue, and burnout in nursing. J Radiol Nurs. 2019 Mar; 38(1):44-46.

12. Maiorano T, Vagni M, Giostra V, Pajardi D. COVID-19: Risk factors and protective role of resilience and coping strategies for emergency stress and secondary trauma in medical staff and emergency workers - an online-based inquiry. Sustainability. 2020;12(21):9004.

13. Kakiashvili T, Leszek J, Rutkowski K. The medical perspective on burnout. Int J Occup Med Environ Health. 2013 Jun;26(3):401-12.

14. Hätinen M, Kinnunen U, Pekkonen M, Kalimo R. Comparing two burnout interventions: perceived job control mediates decreases in burnout. Int J Stress Manag. 2007;14(3):227-248.

15. Rotenstein LS, Torre M, Ramos MA, Rosales RC, Guille C, Sen S, et al. Prevalence of burnout among physicians: a systematic review. JAMA. 2018 Sep 18;320(11):1131-1150.

16. Vinter H. Sindrom sagorijevanja liječnika i pandemija COVID-19. Pliva med; [citirano 6.10.2021.] Dostupno na: http://www.plivamed.net/

17. Galanis P, Vraka I, Fragkou D, Bilali A, Kaitelidou D. Nurses' burnout and associated risk factors during the COVID-19 pandemic: A systematic review and meta-analysis. J Adv Nurs. 2021 Aug;77(8):3286-3302.

18. Gómez-Urquiza JL, Aneas-López AB, FuenteSolana EI, Albendín-García L, Díaz-Rodríguez L, Fuente GA. Prevalence, risk factors, and levels of burnout among oncology nurses: a systematic review. Oncol Nurs Forum. 2016 May 1;43(3):E104-20.

19. Ruiz-Fernández MD, Ramos-Pichardo JD, Ibáñez-Masero O, Cabrera-Troya J, Carmona-Rega MI, Ortega-Galán ÁM. Compassion fatigue, burnout, compassion satisfaction and perceived stress in healthcare professionals during the COVID-19 health crisis in Spain. J Clin Nurs. 2020 Nov;29(2122):4321-4330.

20. Levert T, Lucas M, Ortlepp K. Burnout in psychiatric nurses: contributions of the work environment and a sense of coherence. S Afr J Psychol. 2000;30(2):36-43.

21. Van der Doef M, Mbazzi FB, Verhoeven C. Job conditions, job satisfaction, somatic complaints and burnout among East African nurses. J Clin Nurs. 2012 Jun;21(11-12):1763-75.

22. De la Fuente-Solana EI, Suleiman-Martos N, Pradas-Hernández L, Gomez-Urquiza JL, CañadasDe la Fuente GA, Albendín-García L. Prevalence, related factors, and levels of burnout syndrome among nurses working in gynecology and obstetrics services: a systematic review and meta-analysis. Int J Environ Res Public Health. 2019 Jul 19;16(14):2585.

23. Monsalve-Reyes CS, San Luis-Costas C, GómezUrquiza JL, Albendín-García L, Aguayo R, CañadasDe la Fuente GA. Burnout syndrome and its prevalence in primary care nursing: a systematic 

Mostar za vrijeme covid-19 pandemije. Zdravstveni glasnik. 2021;7(2):59-66.

review and meta-analysis. BMC Fam Pract. 2018 May 10;19(1):59.

24. Pradas-Hernández L, Ariza T, Gómez-Urquiza JL, Albendín-García L, De la Fuente EI, CañadasDe la Fuente GA. Prevalence of burnout in paediatric nurses: A systematic review and metaanalysis. PLoS One. 2018 Apr 25;13(4):e0195039.

25. Adriaenssens J, de Gucht V, Maes S. Determinants and prevalence of burnout in emergency nurses: A systematic review of 25 years of research. Int J Nurs Stud. 2015;52(2):649-61.

26. Liakopoulou M, Panaretaki I, Papadakis V, Katsika A, Sarafidou J, Laskari H, et al. Burnout, staff support, and coping in pediatric oncology. Support Care Cancer. 2008;16(2):143-150.

27. Thakur D, Dhandapani M, Ghai S, Mohanty M,
Dhandapani S. Intracranial tumors: a nurse-led intervention for educating and supporting patients and their caregivers. Clin J Oncol Nurs. 2019 Jun 1;23(3):315-323.

28. Sahoo SK, Dhandapani S, Singh A, Gendle C, Karthigeyan M, Salunke P, et al. COVID-19: changing patterns among neurosurgical patients from North India, efficacy of repeat testing, and inpatient prevalence. Neurosurg Focus. 2020 Dec;49(6):E7.

29. Dhandapani M, Kaur S, Das K, Guru RR, Biswal $\mathrm{M}$, Mahajan P, et al. Enhancing the safety of frontline healthcare workers during coronavirus disease: a novel real-time remote audiovisual aided doffing approach. Infect Dis (Lond). 2021 Feb;53(2):145-147. 


\title{
OTVORENI PRISTUP I ELEKTRONIČKI IZVORI U BIOMEDICINI
}

\author{
Dragana Rašić ${ }^{1}$, Josip Šimić ${ }^{1}$, Marko Odak ${ }^{2}$, Lana Lovrić \\ ${ }^{1}$ Fakultet zdravstvenih studija Sveučilišta u Mostaru \\ ${ }^{2}$ Filozofski fakultet Sveučilišta u Mostaru
}

Rad je primljen 12.07.2021. Rad je recenziran 28.07.2021. Rad je prihvaćen 09.08.2021.

\section{SAŽ̃TAK}

Otvoreno dijeljenje informacija i znanja omogućava njihovu veću protočnost i iskoristivost, a to je najvažnije za razvoj informacijskog društva i društva znanja.

Znanstvena zajednica kontinuirano razmjenjuje informacije o novim znanstvenim otkrićima i činjenicama koji su danas nezamislivi bez potpore informacijske i komunikacijske tehnologije (IKT). Inicijativa i deklaracija koje su se zalagale za otvoreni pristup su: Budimpeštanska inicijativa za otvoreni pristup, Bethesdanska izjava o otvorenom pristupu u izdavaštvu i Berlinska deklaracija o otvorenom pristupu znanstvenim informacijama. Najvažniji medicinski izvori u otvorenom pristupu su Directory of Open Access Journals (DOAJ), PubMed Central (PMC), Public Library of Science (PLoS). Za medicinsku znanost i struku nesmetani i široki pristup pouzdanim i provjerenim informacijama ima izrazito veliku važnost. Potrebno je u svijet znanstvenog izdavaštva uvesti inovacije koje nove tehnologije omogućuju i to u svrhu učinkovitijeg objavljivanja i pristupa. Treba istražiti nove modele poslovanja uključujući otvoreni pristup. Cilj digitalizacije i otvorenog pristupa znanstvenih informacija mora biti osiguravanje trajnosti pristupa informacijama za buduće generacije.

Ključne riječi: otvorena znanost, biomedicina, informacijske i komunikacijske tehnologije

Osoba za razmjenu informacija:

Ime: Dragana Rašić

E-mail: dragana.rasic@fzs.sum.ba 